\title{
Education and Training for Management
}

\begin{abstract}
A DISCUSSION arranged by the Department of A Industrial Co-operation of the Section of Economic Science and Statistics at the York meeting of the British Association was devoted to the selection, training and placing of administrative personnel, including the study of the "Case Method" as an instrument in education and training for management. The discussion was opened by $\mathrm{Mr}$. Jules Menken, of the Department of Business Administration at the London School of Economics. Mr. Menken described the Case method which was originally developed by the Harvard Business School in the United States. The method is used in many other American schools of business administration as well as at the Business Preparation Centre of the Paris Chamber of Commerce but is little known in Great Britain. Essentially the method consists of the discussion in class of problems actually drawn from business experience. A business case or problem sets forth the facts involved in a particular business situation. It is prepared by the students before they come to class and then forms the basis of a conference or discussion. The student is thus trained to analyse types of business situations, to find prineiples on which action must be taken in a particular situation, to formulate a plan of action and to justify his policy and plan in reasoned argument.
\end{abstract}

The successful use of this method depends upon such factors as the selection and training of teaching staff, the development of confidence among the firms associated to secure the provision of material for the cases, and the planning and presentation of the material obtained in a suitable manner. Of fundamental importance is the use of the method with students sufficiently mature in mind and experience to participate in the discussions. The method can be used inductively or deductively but it is relatively unsuited for the teaching of systematised knowledge. Mr. Menken claimed that the method is a valuable instrument for developing a technique of analysis and training the powers of judgment required in business decisions.

The second paper in the discussion was contributed by the Hon. J. F. A. Browne, who outlined some suggestions for co-operation between the universities and industry in the placing of those who have qualified not as specialists such as chemists, engineers, etc., but who have taken a general degree and left the university without a specific vocational qualification. After emphasising the futility of specialised training for business management at the universities, Mr. Browne suggested that it is more important for a man to enter business with a wide general education and a keen mind, trained to learn quickly and accurately, to grasp the essential points of a problem and to analyse a difficult situation. The absence of any agreed demand as to what qualifications are necessary in its recruits, indicates how far industry still is from being professionalised, but industry should regard the universities as a field for recruitment and pay much more attention to machinery for careful and systematic selection of candidates. Bad selection in the past has been largely responsible for much prejudice in industry against university men. Much more of the personal touch is desirable in the work of the Appointments Board particularly in the selection of candidates to be recommended for specified vacancies. Prospective employers should be able to depend on the Appointments Board for a perfectly frank opinion about a man and to regard it as an absolutely reliable source of confidential information. By more careful selection of candidates and particularly by warning them from applying for posts for which they appeared to be unsuitable, the Board could render genuine service to its candidates and prevent the development of an inferiority complex in the minds of those who might otherwise continually apply without success for posts for which they were unsuitable. Efficient selection by the Board, however, depends essentially on industry telling the Appointment Boards frankly what it requires in particular vacancies and in furnishing particulars of the appointment, its duties and prospects comparable in fulness of detail with those supplied by Government regarding Government appointments. Extension of the organised training schemes now being developed by industry is of real value and the Management Research Groups might well explore the possibilities of co-operation in this field, particularly in securing a common approach between different firms and the university appointments boards.

\section{The Wren Tercentenary}

7 HE loan exhibition of portraits, architectural drawings, models, manuscripts, and personal relics illustrative of the life and times of Sir Christopher Wren, brought together in the Trophy Room by the Dean and Chapter of St. Paul's Cathedral, is now open to the public view, and will undoubtedly ensure large attendances, for Wren is secure in the nation's affectionate regard. Very suitably the opening of the exhibition was undertaken by Sir Frederick Gowland Hopkins, president of the Royal Society, who delivered a brief address dealing with various aspects of Wren's many-sided career.

The catalogue of the exhibits contains 168 entries of objects ; happily it does not err on the score of meagre description. It would, perhaps, have been helpful to have supplied such an important issue as this-one doubtless destined to circulate all over the world-with a preface embodying the main everts of Wren's life, in particular, at least, the series culminating in his great architectural achievement.

Several portraits of Wren at varying ages are shown. These include the small full-length, attributed to Gascar, 1674-80, from Welbeck Abbey, the portrait in the Sheldonian Theatre, Oxford, presumed to be by Sir James Thornhill (about 1675), the St. Paul's modified copy of the Kneller in the National Portrait Gallery (1711), and the Royal Society's portrait, painter uncertain. There is also the Wren death mask, lent by All Souls' College, Oxford. On a sheet of foolscap size appears the following: "I will give one thousand pounds a yeare. Whithall 20 March $\frac{7}{1678}$. Charles R."- 